\title{
Penerapan Model Pembelajaran Cooperative Script Berbantuan Media LKS untuk Meningkatkan Kemampuan Pemecahan Masalah Matematis Siswa pada Materi Aljabar
}

\author{
Nindy Citroresmi Prihatiningtyas ${ }^{1}$, Rika Wahyuni $^{2}$, Rani Milantika ${ }^{3}$ \\ STKIP Singkawang, Singkawang, Indonesia \\ nindy.citroresmi@yahoo.com ${ }^{1, *)}$, rikawahyuni142@gmail.com ${ }^{2}$, ranimilantika@gmail.com ${ }^{3}$ \\ ${ }^{*}$ Corresponding author
}

\section{Kata Kunci:}

Cooperative Script; Kemampuan

Pemecahan Masalah; Aljabar

\begin{abstract}
ABSTRAK
Penelitian ini bertujuan: (1) Untuk mengetahui perbedaan peningkatan kemampuan pemecahan masalah matematis siswa terhadap model pembelajaran Cooperative Script pada materi aljabar; (2) Untuk mengetahui keterlaksanaan model pembelajaran Cooperative Script terhadap kemampuan pemecahan masalah matematis siswa pada materi aljabar; (3) Untuk mengetahui motivasi belajar siswa setelah diterapkannya model pembelajaran Cooperative Script pada materi aljabar; Jenis penelitian ini adalah penelitian kuantitatif dengan metode Quasi Eksperimental Design dengan bentuk Non Equivalent Control Group Design. Instrumen yang digunakan adalah tes kemampuan pemecahan masalah matematis siswa, lembar keterlaksanaan pembelajaran dan angket motivasi belajar siswa. Hasil analisis data menunjukkan bahwa: (1) Terdapat perbedaan peningkatan kemampuan pemecahan masalah matematis siswa; (2) Keterlaksanaan pembelajaran menggunakan model pembelajaran Cooperative Script berada pada kriteria baik; (3) Motivasi belajar siswa setelah diajarkan dengan model Cooperative Script tergolong sangat tinggi.
\end{abstract}

\section{PENDAHULUAN}

Matematika merupakan ilmu yang mendasari perkembangan teknologi modern dan mempunyai peranan penting dalam berbagai disiplin ilmu dan memajukan daya pikir manusia (Sari, Wahyuni, \& Rosmaiyadi, 2016). Di dalam pembelajaran Matematika, idealnya siswa dibiasakan untuk memperoleh pemahaman melalui pengalaman dan pengetahuannya yang dikembangkan oleh siswa sesuai dengan perkembangan berpikirnya (Citroresmi \& Nurhayati, 2017). National of Caouncil Teacher of Mathematical (NCTM, 2000:67) menyatakan standar proses dalam matematika meliputi pemecahan masalah (problem solving), penalaran dan pembuktian (reasoning and proof), keterkaitan (connections), komunikasi (communication) dan representasi (representation). Proses ini dilakukan agar siswa memiliki kemampuan pemahaman konsep, kelancaran prosedur dan pemecahan masalah.

Dari pernyataan diatas diketahui bahwa kemampuan pemecahan masalah tidak hanya dilihat dari hasil atau kemampuan yang muncul dari dalam diri siswa, melainkan proses yang diperoleh siswa sehingga siswa terampil dalam memecahkan masalah. Dapat ditarik kesimpulan bahwa dalam pembelajaran 
siswa harus dilatih dan dibiasakan dalam memecahkan suatu masalah melalui tahapan-tahapan tertentu.

Tujuan mata pelajaran matematika untuk Sekolah Menengah Pertama menurut Badan Standar Nasional Pendidikan (BSNP) (2006: 30) yaitu siswa memiliki kemampuan memecahkan masalah yang meliputi kemampuan memahami masalah, merancang model matematika, menyelesaikan model, dan menafsirkan solusi yang diperoleh. Didalam pembelajaran matematika kegiatan yang utama adalah memecahkan masalah matematika itu sendiri, dijelaskan bahwa salah satu indikasi adanya transfer belajar adalah adanya kemampuan siswa dalam memecahkan masalah (Nur \& Wikandri, 2004).

Kemampuan pemecahan masalah merupakan satu diantara bagian yang penting di dalam kurikulum matematika, karena di dalam proses pembelajaran maupun penyelesaian siswa memungkinkan untuk dapat memperoleh pengetahuan serta menggunakan pengetahuan yang sudah dimiliki untuk digunakan dalam pemecahan masalah. Kemampuan penyelesaian (pemecahan) masalah menjadi tujuan utama diantara beberapa tujuan belajar matematika (Citroresmi \& Nurhayati, 2017). Namun pada kenyataannya masih banyak siswa kesulitan dalam memecahkan masalah karena kurangnya pengetahuan untuk memperjelas masalah sehingga masalah tersebut tidak dapat diselesaikan (Nur \& Wikandri, 2004).

Berdasarkan hasil dari Trends in International Mathematics and Science Study (TIMSS) (2011), skor prestasi matematika dari pelajar Indonesia berada di rangking bawah yaitu 38 dari 42 negara. Selain itu hasil penelitian oleh Primandiri (2010) juga menyatakan bahwa di SMP Negeri 2 Nanggulan kemampuan pemecahan masalah matematis siswa masih rendah. Hal ini dapat dilihat dari hasil ujian matematika tengah semester dengan soal yang mengandung indikator pemecahan masalah menyatakan bahwa persentase siswa kelas VII A yang memiliki nilai sama dengan atau diatas nilai KKM hanya mencapai $52,77 \%$.

Hal serupa juga terjadi pada siswa kelas VIII SMPN 20 Singkawang bahwa kemampuan pemecahan masalah matematis siswa tergolong rendah. Sebagian besar siswa mengalami kesulitan dalam menyelesaikan masalah yang disajikan dalam bentuk soal cerita, membuat model matematis dan menuliskan penjelasan dari jawaban permasalahan secara matematis. Berdasarkan observasi yang dilakukan didalam kelas motivasi belajar siswa tergolong rendah. Hal ini disebabkan siswa kurang aktif dalam mencari sumber, siswa tidak memiliki semangat untuk membuka buku catatan, mengolah informasi, mengajukan pertanyaan dan mengerjakan latihan yang diberikan. Akibatnya siswa hanya terpaku pada hasil bukan pada proses mendapatkan hasil sehingga kesulitan dalam memecahkan masalah yang ada pada soal.

Rendahnya motivasi siswa tentu menjadi salah satu masalah yang serius, sebab motivasi belajar merupakan satu diantara hal-hal penting di dalam proses pembelajaran untuk mencapai tujuan pembelajaran. Pentingnya motivasi belajar ini dikemukakan oleh Aunurrahman (2012: 180) yang menyatakan bahwa motivasi merupakan penggerak yang mendorong siswa untuk berperan lebih aktif dalam mengikuti pembelajaran agar tercapainya tujuan pembelajaran. Menyadari akan rendahnya kemampuan pemecahan masalah siswa dalam pembelajaran matematika maka diperlukan model pembelajaran yang tepat untuk meningkatkan kemampuan pemecahan masalah matematis siswa dalam pembelajaran matematika khususnya pada materi aljabar. Salah satunya dengan menerapkan model pembelajaran Cooperative Script.

Model pembelajaran Cooperative Script adalah model pembelajaran di mana siswa bekerja berpasangan dan bergantian secara lisan mengikhtisarkan, bagian-bagian dari materi yang di pelajari Yustisia (2007: 165). Dengan menggunakan model pembelajaran Cooperative Script diharapkan dapat meningkatkan kemampuan pemecahan masalah matematis siswa. Model pembelajaran Cooperative Script dapat membantu siswa berfikir secara sistematis berkonsentrasi pada materi pelajaran, siswa dilatih untuk saling bekerja sama satu sama lain dalam suasana yang menyenangkan. Dari uraian pada latar belakang tersebut, maka perlu dilakukan penelitian tentang Penerapan Model Pembelajaran 


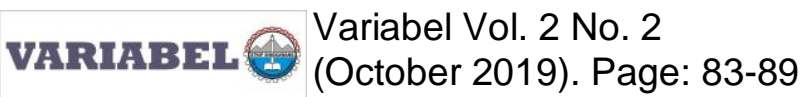

Cooperative Script dengan berbantuan Media LKS untuk meningkatkan Kemampuan Pemecahan Masalah Matematis Siswa pada Materi Aljabar.

\section{METODE PENELITIAN}

Penelitian ini adalah jenis penelitian kuantitatif dengan metode eksperimen, penelitian ini menggunakan d Quasi Eksperimental Design dengan bentuk Nonequivalent Control Group Design. Tahap pertama dilakukan pengukuran (pre-test), kemudian tahap kedua dikenakan perlakuan (treatment) dan tahap ketiga diakhiri dengan pengukuran kembali (post-test). Rancangan penelitian dapat dilihat pada Tabel 1 (Sugiyono, 2014).

Tabel 1. Rancangan Penelitian

\begin{tabular}{rcc}
\hline Pre-test & Perlakuan & Post-test \\
\hline$O_{1}$ & $X_{1}$ & $O_{2}$ \\
$O_{3}$ & $X_{2}$ & $O_{4}$ \\
\hline
\end{tabular}

Keterangan:

$O_{1}=$ Pre-test kelas eksperimen

$X_{1}=$ Perlakuan menggunakan model pembelajaran Cooperative Script

$\mathrm{O}_{2}=$ Post-test kelas eksperimen

$\mathrm{O}_{3}=$ Pre-test kelas kontrol

$X_{2}=$ Perlakuan menggunakan pembelajaran langsung

$\mathrm{O}_{4}=$ Post-test kelas kontrol

Populasi dalam penelitian ini adalah semua peserta didik kelas VIII SMPN 20 Singkawang yang terdiri dari 3 kelas yaitu VIII A, VIII B dan VIII C. Sedangkan sampel dalam penelitian ini adalah kelas VIII B sebagai kelas eksperimen dan kelas VIII A sebagai kelas kontrol Teknik pengambilan sampel yang digunakan dalam penelitian ini dengan teknik sampling purposive. Teknik pengumpulan data dalam penelitian ini adalah tes kemampuan pemecahan masalah, lembar pengamatan keterlaksanaan, angket motivasi belajar. Instrumen pengumpulan data dalam penelitian ini yaitu: (a) soal-soal uraian yang diberikan dalam bentuk pretest dan posttest yang merupakan tes kemampuan pemecahan masalah yang sesuai dengan indikator-indikator untuk mengukur tingkat kemampuan pemecahan masalah metematis siswa; (b) lembar keterlaksanaan pembelajaran yang diberikan menggunakan rumus presentase frekuensi keterlaksanaan $\left(f_{k}\right)$ yaitu dengan mengukur seluruh indikator dari masing-masing pengamat; (c) angket motivasi belajar siswa, angket ini digunakan untuk mengukur tingkat motivasi belajar siswa menggunakan model pembelajaran Cooperative Script.

Data yang akan dianalisis dalam penelitian ini diperoleh dari tes kemampuan pemecahan masalah matematis, tes dilakukan pada awal pembelajaran (pretest) kemudian diberi perlakuan (treatment) dan diberi tes pada akhir pembelajaran (posttest). Dari skor pretest dan postest yang telah diperoleh dihitung rata-rata hasil pretest dan postest lalu dilihat peningkatan (gain ternormalisasi) kemampuan pemecahan masalah matematis dari hasil kedua tes tersebut.

Selain data tes, data hasil lembar keterlaksanaan pembelajaran dan data motivasi siswa juga dianalisis. Data keterlaksanaan pembelajaran dianalisis dengan menghitung presentase keterlaksanaan keseluruhan dari hasil kedua pengamat. Data motivasi siswa dianalisis dengan menghitung persentase siswa yang memilih suatu kategori atau kriteria dengan jalan banyaknya siswa yang memilih suatu kategori atau kriteria dibagi dengan jumlah butir tanggapan dikali dengan jumlah banyaknya siswa. Setelah dilakukan perhitungan barulah kemudian disimpulkan berdasarkan interpretasi motivasi. 


\section{HASIL DAN PEMBAHASAN}

\section{Kemampuan Pemecahan Masalah Matematis Siswa}

Hasil pengolahan skor pretest dan posttest kemampuan pemecahan masalah matematis pada kelas eksperimen dan kelas kontrol juga diperoleh skor terendah, dan skor tertinggi, rerata dan simpangan baku. Adapun deskripsi data pretest dan posttest kemampuan pemecahan masalah matematis siswa secara keseluruhan kelas eksperimen dan kelas kontrol dapat dilihat pada Tabel 2.

Tabel 2. Rekapitulasi Data Pretest dan PosttestKemampuan Pemecahan Masalah Matematis Siswa

\begin{tabular}{|c|c|c|c|c|c|c|c|c|c|}
\hline \multirow{2}{*}{ Kelas } & \multirow{2}{*}{$\mathbf{N}$} & \multicolumn{2}{|c|}{ Skor Terendah } & \multicolumn{2}{|c|}{ Skor Tertinggi } & \multicolumn{2}{|c|}{ Rata-rata } & \multicolumn{2}{|c|}{$\begin{array}{c}\text { Simpangan } \\
\text { Baku }\end{array}$} \\
\hline & & $\begin{array}{c}\text { Pre- } \\
\text { test }\end{array}$ & $\begin{array}{c}\text { Post- } \\
\text { test }\end{array}$ & $\begin{array}{l}\text { Pre- } \\
\text { Test }\end{array}$ & $\begin{array}{c}\text { Post- } \\
\text { Test }\end{array}$ & $\begin{array}{c}\text { Pre- } \\
\text { test }\end{array}$ & $\begin{array}{c}\text { Post- } \\
\text { test }\end{array}$ & $\begin{array}{c}\text { Pre- } \\
\text { test }\end{array}$ & $\begin{array}{c}\text { Post- } \\
\text { test }\end{array}$ \\
\hline Eksperimen & 26 & 4 & 10 & 15 & 27 & 1,44 & 2,73 & 1,20 & 1,65 \\
\hline Kontrol & 26 & 2 & 9 & 11 & 22 & 0,88 & 1,65 & 0,94 & 1,29 \\
\hline
\end{tabular}

Tabel 2 menunjukkan skor rata-rata Pretest kemampuan pemecahan masalah matematis kelas eksperimen adalah 1,44 dan kelompok kontrol 0,88 perolehan skor rata-rata posttest kemampuan pemecahan masalah matematis siswa kelas eksperimen adalah 2,73 dan kelompok kontrol adalah 1,65, secara deskripsi terlihat bahwa data skor rata-rata pretest kelompok eksperimen dan kontrol berbeda dengan skor rata-rata posttest kelompok eksperimen dan kontrol tidak sama selanjutnya untuk mengetahui peningkatan kemampuan pemecahan masalah matematis siswa antara kelas eksperimen dan kelas kontrol harus dilakukan analisis terhadapan gain ternormalisasi.

a. Hasil Peningkatan Kemampuan Pemecahan Masalah Matematis

Dari hasil dari skor pretest dan posttest kemampuan pemecahan masalah matematis siswa pada kelas eksperimen dan kontrol, selanjutnya dilihat peningkatan (gain ternormalisasi) kemampuan pemecahan masalah matematis dari kedua kelas tersebut berdasarkan skor pretest dan posttest. Adapun rekapitulasi hasil perhitungan $\mathrm{N}$-Gain berdasarkan tiap indikator kemampuan pemecahan masalah matematis siswa dapat ditunjukan pada Gambar 1.

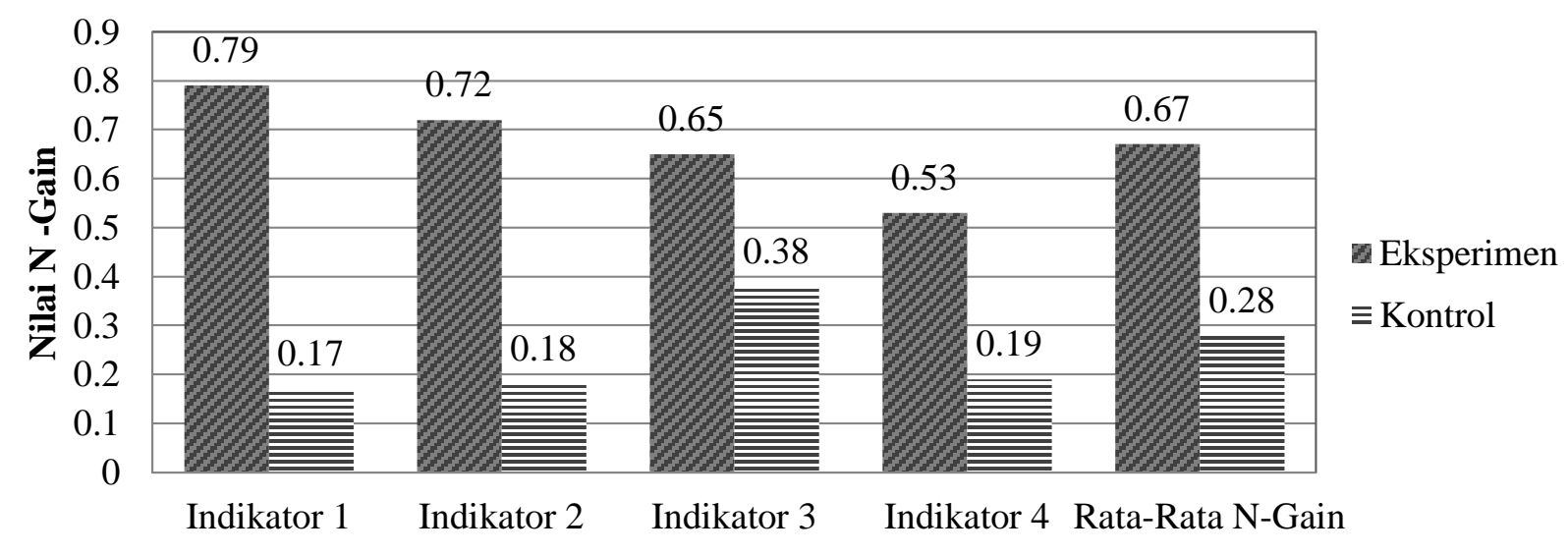

Gambar 1. Rekapitulasi N-Gain Tiap Indikator Kemampuan Pemecahan Masalah Matematis Siswa

Keterangan:

Indikator 1 = Mengidentifikasi unsur-unsur dan kecakupan unsur yang diperlukan

Indikator $2=$ Merumuskan masalah matematis

Indikator $3=$ Menerapkan strategi dan penyelesaian masalah

Indikator 4 = Menjelaskan dan menginterpretasikan hasil

Gambar 1 secara deskripsi terlihat bahwa data keseluruhan indikator kemampuan pemecahan masalah matematis siswa kelompok eksperimen dan kontrol tidak sama dimana rata-rata N-Gain pada kelas 
eksperimen dengan nilai 0,67 berada pada kategori sedang, sedangkan pada kelas kontrol dengan nilai 0,28 dengan kategori rendah. Dapat diketahui bahwa peningkatan kemampuan pemecahan masalah matematis siswa pada kelas yang menggunakan model pembelajaran Cooperative script lebih tinggi dari kelas yang menggunakan pembelajaran langsung. Selanjutnya data setiap siswa dikategorikan berdasarkan kriteria Indeks N-Gain dapat dilihat pada Tabel 3.

Tabel 3. Data Jumlah Siswa Berdasarkan Kriteria Indeks N-Gain

\begin{tabular}{ccc}
\hline \multirow{2}{*}{ Kriteria Indeks N-Gain } & \multicolumn{2}{c}{ Jumlah Siswa } \\
\cline { 2 - 3 } & Kelas Eksperimen & Kelas Kontrol \\
\hline Tinggi & 16 & 1 \\
Sedang & 5 & 9 \\
Rendah & 5 & $\mathbf{2 6}$ \\
\hline Jumlah & $\mathbf{2 6}$ & \\
\hline
\end{tabular}

Tabel 3 dapat dilihat bahwa kemampuan pemecahan masalah matematis siswa berdasarkan kriteria indeks N-Gain pada kelas eksperimen berjumlah 16 siswa dengan kategori tinggi, 5 siswa kategori dengan sedang dan 5 siswa dengan kategori rendah, sedangkan kemampuan pemecahan masalah matematis siswa pada kelas kontrol terdapat 1 siswa dengan kategori tinggi, 9 siswa kategori sedang dan terdapat 16 siswa dengan kategori rendah.

b. Perbedaan Peningkatan Kemampuan Pemecahan Masalah Matematis Siswa

Agar terdapat perbedaan peningkatan kemampuan pemecahan masalah matematis siswa antara kelas yang menggunakan model pembelajaran Cooperative Script dan kelas yang menggunakan pembelajaran langsung (kelas kontrol) maka menggunakan uji-t dua sampel. Sebelum uji-t dua sampel digunakan maka terlebih dahulu menggunakan uji normalitas.

Dari hasil perhitungan uji normalitas pada kelas eksperimen diperoleh harga $x^{2}$ hitung $=51,9753$ dan $x^{2}$ tabel $=11,070$. Karena $x^{2}$ hitung $>x^{2}$ tabel maka $H_{0}$ ditolak dan $H_{a}$ diterima, artinya data yang berada pada kelompok eksperimen tidak berdistribusi normal. Pada hasil perhitungan uji normalitas pada kelompok kontrol, diperoleh harga $x^{2}$ hitung $=11,4331$, sedangkan $x^{2}$ tabel $=11,070$. Karena $x^{2}$ hitung $>x^{2}$ tabel maka $H_{0}$ ditolak dan $H_{a}$ diterima, artinya data yang berada pada kelompok kontrol tidak berdistribusi normal. Oleh karena pada kelas eksperimen dan kontrol tidak berdistribusi normal maka selanjutnya menggunakan uji Man Whitney U-Test. Adapun rekapitulasi hasil uji Man Whitney U-Test dapat dilihat pada Tabel 4.

Tabel 4. Rekapitulasi Perhitungan Uji Man Whitney U-Test

\begin{tabular}{ccccccc}
\hline Keterangan & $\boldsymbol{n}_{\mathbf{1}}$ & $\boldsymbol{n}_{\mathbf{2}}$ & $\mathbf{U}_{\mathbf{1}}$ & $\mathbf{U}_{\mathbf{2}}$ & $\mathbf{E}(\mathbf{U})$ & $\operatorname{Var}(\mathbf{U})$ \\
\hline Skor & 26 & 26 & 138,5 & 606,5 & 338 & 2985,66 \\
$\boldsymbol{Z}_{\text {hitung }}$ & & & & $-3,65$ & & \\
$-\boldsymbol{Z}_{\text {tabel }}$ & & & & $-1,96$ & & \\
\hline
\end{tabular}

Berdasarkan Tabel 5 dapat diketahui bahwa nilai $Z_{\text {hitung }}=-3,65<Z_{\text {tabel }}=-1,96$, maka Ho ditolak. Hal ini dapat disimpulkan bahwa terdapat perbedaan penggunaan model pembelajaran Cooperative Script dan model pembelajaran langsung terhadap kemampuan pemecahan masalah matematis siswa pada materi aljabar kelas VIII SMP Negeri 20 Singkawang.

\section{Keterlaksanaan Model Pembelajaran Cooperative Script}

Hasil keterlaksanaan model pembelajaran Cooperative Script merupakan data yang diperoleh dari lembar pengamatan keterlaksanaan yang dilakukan oleh dua orang pengamat yaitu satu orang guru matematika dan satu orang mahasiswa. Pengamatan keterlaksanaan ini hanya diamati di kelas eksperimen dan dilakukan sebanyak dua kali pertemuan yang menggunakan model pembelajaran Cooperative Script pada materi aljabar. Adapun hasil analisis penelitian data lembar keterlaksanaan model pembelajaran Cooperative Script ditampilkan pada Tabel 5. 
Tabel 5. Rekapitulasi Keterlaksanaan Model Pembelajaran Cooperative Script

\begin{tabular}{ccccc}
\hline Keterangan & Pertemuan 1 & Pertemuan 2 & $\begin{array}{c}\text { Rata-rata tiap } \\
\text { pertemuan }\end{array}$ & $\begin{array}{c}\text { Rata-rata } \\
\text { keseluruhan }\end{array}$ \\
\hline Pengamat 1 & $80 \%$ & $94 \%$ & 82,5 & \\
Pengamat 2 & (Baik) & (Sangat Baik) & $($ Baik) & $89 \%$ \\
& $85 \%$ & $95 \%$ & $94,50 \%$ & (Sangat Baik) \\
(Sangat Baik) & (Sangat Baik) & (Sangat Baik) & \\
\hline
\end{tabular}

Tabel 5 menunjukan bahwa hasil keterlaksanaan model pembelajaran Cooperative script secara keseluruhan dari dua pengamat pada pertemuan pertama dan pertemuan kedua diperoleh presentase sebesar $89 \%$, dengan kategori sangat baik, dari hasil tersebut menunjukan bahwa keterlaksanaan model pembelajaran Cooperative Script dapat meningkatkan kemampuan pemecahan masalah matematis siswa.

Sejalan dengan penelitian yang dilakukan Khotimah (2018) menunjukan bahwa pengamatan keterlaksanaan pada pertemuan pertama yang memuat lima belas kegiatan diperoleh persentase sebesar $67,5 \%$, sedangkan pada pertemuan kedua yang memuat lima belas kegiatan memperoleh persentase sebesar $72,5 \%$. Kemudian melihat persentase rata-rata dari dua kali pertemuan yang memperoleh persentase sebesar $70 \%$, maka keterlaksanaan model pembelajaran Learning Cycle $7 E$ dikategorikan baik.

\section{Motivasi belajar Siswa}

Motivasi belajar siswa diperoleh dari pemberian angket motivasi pada masing-masing siswa, angket motivasi berisikan dua pernyataan yaitu pernyataan negatif dan pernyataan positif dimana siswa mengisi angket tersebut berdasarkan hasil dari proses pembelajaran yang telah berlangsung, adapun hasil motivasi belajar siswa dapat dilihat pada Tabel 6 .

Tabel 6. Rekapitulasi Hasil Angket Motivasi Belajar Siswa

\begin{tabular}{cccc}
\hline $\begin{array}{c}\text { Jumlah Rata-rata Skor } \\
\text { Seluruh Siswa }\end{array}$ & $\begin{array}{c}\text { Jumlah } \\
\text { Siswa }\end{array}$ & $\begin{array}{c}\text { Rata-rata Seluruh Hasil Angket } \\
\text { Siswa }(\bar{x})\end{array}$ & Kriteria \\
\hline 113,36 & 26 & 4,36 & Sangat tinggi \\
\hline
\end{tabular}

Dari Tabel 6 dapat dilihat bahwa skor rata-rata seluruh hasil angket motivasi belajar siswa setelah diberikannya model pembelaran Cooperative Script sebesar 4,36 kategori sangat tinggi, dengan ratarata motivasi belajar siswa untuk pernyataan positif sebesar 4,36 dan rata-rata motivasi belajar siswa untuk pernyataan negatif sebesar 4,37. Dari hasil tersebut dapat dikatakan bahwa dengan menggunakan model pembelajaran Cooperative Script dapat meningkatkan motivasi belajar siswa selama proses pembelajaran berlangsung didalam kelas.

Dalam hal ini sejalan dengan penelitian yang dilakukan oleh Sjukur (2012) menyatakan bahwa terdapat perbedaan motivasi belajar antara siswa yang diajar pembelajaran blended learning dibandingkan siswa yang diajar pembelajaran konvensional mengalami peningkatan dimana dengan nilai signifikan diperoleh sebesar 0,012 dengan rata-rata 4,74 dan terdapat perbedaan hasil belajar dengan nilai signifikan sebesar 0,000 dengan rata-rata 13,39. Ada peningkatan motivasi belajar siswa akibat penerapan pembelajaran blended learning dengan rata-rata peningkatan sebesar 13,55.

Siregar dan Nara (2014:49) menyatakan motivasi adalah penggerak dalam diri seseorang untuk melakukan aktivitas-aktivitas demi mencapai tujuan tertentu, oleh karena itu motivasi belajar adalah sesuatu yang mendorong siswa unutk belajar dengan penuh semangat. Sedangkan menurut Lestari dan Yudhanegara (2015: 93) motivasi belajar adalah suatu daya, dorongan atau kekuatan, baik yang datang dari diri sendiri maupun dari luar yang mendorong peserta didik untuk belajar. 


\section{KESIMPULAN}

Berdasarkan analisis data hasil penelitian yang dilakukan dan pembahasan secara umum dapat disimpulkan bahwa terdapat perbedaan peningkatan kemampuan pemecahan masalah matematis siswa antara penerapan model pembelajaran Cooperative Script dengan penerapan model pembelajaran langsung pada materi aljabar kelas VIII. Model pembelajaran Cooperative Script terlaksana dengan baik pada materi aljabar sesuai dengan yang direncanakan. Motivasi belajar siswa tergolong tinggi terhadap model pembelajaran Cooperative Script dengan rata-rata motivasi seluruh siswa berada pada kriteria sangat tinggi.

\section{DAFTAR PUSTAKA}

Aunurrahman. (2012). Belajar dan Pembelajaran. Bandung: Alfabeta

BSNP. (2006). Draft Final Kurikulum Tingkat Satuan Pendidikan Standar Kompetensi Mata Pelajaran Matematika Sekolah Menengah Pertama dan Madrasah Tsanawiyah. Jakarta: Depdiknas.

Citroresmi, N \& Nurhayati. (2017). Penerapan Model Pembelajaran Means-Ends Analysis Untuk Meningkatkan Kemampuan Pemecahan Masalah Matematis Siswa. JPMI (Jurnal Pendidikan Matematika Indonesia), 2(1), 13-18.

Depdiknas. (2003). Kurikulum 2004, Standart Kompetensi. Jakarta: Pusat Kurikulum. Balitang.

Khotimah, N. (2018). Penerapan Model Learning Cycle 7E Untuk Meningkatkan Kemampuan Literasi Matematis Siswa Kelas VIII Pada Materi Prisma. JPMI (Jurnal Pendidikan Matematika Indonesia), 3(1), 15-20.

Lestari, dan Yudhanegara. (2015). Penelitian Pendidikan Matematika. Bandung: PT Refika Aditama.

NCTM. (2000). Principles and Standards for School Mathematics. United States of America: The National Council of Teachers of Mathematics. Inc.

Novianti, E., Isrok'atun, \& Kurniadi, Y. (2016). Pendekatan Eksploratif untuk Meningkatkan Kemampuan Pemecahan Masalah Matematis dan Motivasi Belajar Siswa. Jurnal Pena Ilmiah, $1(1), 401-410$.

Nur, dan Wikandri. (2004). Pengajaran Berpusat pada Siswa dan Pendekatan Kontruktivis dalam Pengajaran. Surabaya: Pusat Sains dan Matematika Sekolah Universitas Negeri Surabaya.

Primandiri. (2010). Upaya Meningkatkan Kemampuan Pemecahan Masalah Siswa Kelas VIII A SMPN 2 Nanggulan Dalam Pembelajaran Matematika Pokok Bahasan Bangun Ruang Menggunakan Model Pembelajaran Kooperatif Tipe Think Pair Square. Skripsi. Fakultas Matematika Dan Ilmu Pengetahuan Alam, Universitas Negeri Yogyakarta. Tidak Dipublikasikan.

Sari, A.N., Wahyuni, R., \& Rosmaiyadi. (2016). Penerapan Pendekatan Open-Ended untuk Meningkatkan Kemampuan Berpikir Kritis Siswa Pada Materi Aljabar Kelas VIII SMP Negeri 10 Pemangkat. JPMI (Jurnal Pendidikan Matematika Indonesia), 1(1), 20-24.

Siregar, \& Nara. (2014). Metode Penelitian Kuantitatif Dilengkapi Dengan Perbandingan Perhitungan Manual dan SPSS. Jakarta: Kencana Prenadamedia Group.

Sjukur, B. (2012) Pengaruh Blended Learning Terhadap Motivasi Belajar dan Hasil Belajar Siswa Tingkat SMK. Jurnal Pendidikan Vokasi, 2(3), 368-378.

Sugiyono. (2014). Metode Penelitian Kuantitatif, Kualitatif dan $R \&$ D. Bandung: Alfabeta.

TIMSS. (2011). International Result in Mathematics. USA: TIMSS \& PIRLS International Study Center and IEA.

Yustisia. (2007). Panduan Lengkap KTSP (Kurikulum Tingkat Satuan Pendidikan). Yogyakarta: Pustaka Yustisia. 